\title{
HASIL PENILAIAN KINERJA DAN CAPAIAN KOMPETENSI GURU (SMAN 2 BANJARMASIN DAN SMAN 13 BANJARMASIN) \\ Rusnailah $^{1}$
}

\section{Pengawas Sekolah Menengah \\ Dinas Pendidikan dan Kebudayaan Provinsi Kalimantan Selatan rusnailah@gmail.com (0812 5081 8090)}

\begin{abstract}
ABSTRAK
Keberhasilan pendidikan dapat ditentukan oleh banyak faktor, antara lain oleh faktor guru, siswa, sarana dan prasarana, lingkungan pendidikan, dan kurikulum. Dari beberapa faktor tersebut, faktor guru dalam kegiatan proses pembelajaran di sekolah menempati kedudukan yang sangat penting. Untuk mengukur keberhasilan sebuah proses pembelajaran diperlukan suatu evaluasi secara terus menerus melalui kegiatan evaluasi kinerja guru oleh setiap sekolah terhadap keseluruhan indikator keberhasilan guru dalam pembelajaran. Atas dasar pemikiran tersebut, perlu dilaksanakan analisis hasil pelaksanakan evaluasi kinerja yang dilaksanakan oleh setiap sekolah, untuk mendapatkan gambaran secara rinci dan spesifik tentang indikator keberhasilan dan kekurangan guru terhadap kompetensi profesi guru yang terdiri atas kompetesi pedagogik, kepribadian, sosial dan profesional. Penelitian ini bertujuan untuk mengetahui seberapa besar tingkat capaian kompetensi profesi guru berdasarkan pertimbangan kepangkatan seseorang. Hasil evaluasi dapat menjadi bahan pertimbangan dan acuan setiap pengawas sekolah dalam menjalankan tugas dan tanggung jawabnya selaku pembina satuan pendidikan. Selain itu, hasil penilaian kinerja juga dapat kerangka acuan bagi Kepala Sekolah dan Pengawas Pembina dalam menyusun program pembinaan, melaksanakan dan menetapkan sasaran pelaksanaan supervisi akademik di sekolah tersebut.
\end{abstract}

Kata Kunci: Penilaian, Kinerja, Kompetensi Guru

\section{A. Latar Belakang Masalah}

\section{PENDAHULUAN}

Guru sebagai salah satu faktor penentu keberhasilan dan peningkatan kualitas pendidikan di seluruh satuan pendidikan menjadi hal yang sangat urgen yang perlu mendapat perhatian dari semua pemangku kebijakan, mengingat guru merupakan bagian yang tidak terpisahkan dari sistem pendidikan yang secara langsung terlibat dalam proses pembelajaran.

Pembelajaran yang efektif sangat tergantung dengan kemampuan guru dalam pengelolaan pembelajaran, kemapuan guru dalam memahami berbagai kompetensi menjadi prasyarat utama bagi seorang guru dalam menyelenggaraan pembelajaran yang efektif. Pembelajaran efektif adalah pembelajaran yang dapat mengkondisikan siswa mencapai kemajuan secara maksimal sesuai dengan kemampuan yang dimilikinya. Oleh karenanya, seorang guru yang baik akan selalu mengupayakan terciptanya kondisi pembelajaran yang efektif, guna terwujudnya tujuan dari proses pembelajaran. 
Terwujudnya pembelajaran yang efektif tidak terlepas dari upaya yang dilaksanakan oleh semua komponen sekolah khususnya guru itu sendiri terhadap kelancaran pelaksanaan proses pembelajaran yang dipersiapkan, yang terimplementasi dalam proses pembelajaran. Standar proses meliputi perencanaan proses pembelajaran, pelaksanaan proses pembelajaran, penilaian hasil pembelajaran, dan pengawasan proses pembelajaran untuk terlaksananya proses pembelajaran yang efektif dan efisien.

Untuk mengukur keberhasilan sebuah proses pembelajaran diperlukan suatu evaluasi secara kontinue melalui kegiatan evaluasi kinerja guru oleh setiap sekolah terhadap keseluruhan indikator keberhasilan guru dalam pembelajaran. Atas dasar pemikiran tersebut, perlu dilaksanakan analisis hasil pelaksanakan evaluasi kinerja yang dilaksanakan oleh setiap sekolah, untuk mendapatkan gambaran secara rinci dan spesifik tentang indikator keberhasilan dan kekurangan guru terhadap kompetensi profesional guru khususnya berkenaan dengan kompetensi pembelajaran.

\section{B. Permasalahan}

Berdasarkan latar belakang di atas, rumusan masalah penelitian ini adalah: (1) Seberapa besar kinerja guru tentang kemampuan menjabarkan kompetensi pedagogik dalam proses pendidikan dan pembelajaran di sekolah, (2) Seberapa besar kinerja guru tentang kemampuan menjabarkan kompetensi kepribadian dalam proses pembelajaran dan proses pendidikan di sekolah, (3) Seberapa besar kinerja guru tentang kemampuan menjabarkan kompetensi sosial dalam proses pendidikan dan pembelajaran di dalam maupun di luar kelas dan (4) Seberapa besar kinerja guru tentang kemampuan menjabarkan kompetensi profesional pendidikan dan pembelajaran di dalam maupun di luar kela

\section{Tujuan / Manfaat Penelitian}

\section{Tujuan Penelitian}

Tujuan Penelitian ini adalah: (1) Menjelaskan tingkat kompetensi pedagogik guru berdasarkan jabatan fungsional guru di sekolah binaan, (2) Menjelaskan tingkat kompetensi sosial guru berdasarkan jabatan fungsional di sekolah binaan. (3) Menjelaskan tingkat kompetensi kepribadian guru berdasarkan jabatan fungsional guru di sekolah binaan, dan (4) Menjelaskan tingkat kompetensi profesional guru berdasarkan jabatan fungsional guru di sekolah binaan.

\section{Manfaat Penelitian}

Hasil penelitian ini diharapkan dapat memberikan gambaran kepada pemangku kepentingan, Sekolah Binaan dan kelompok Musyawarah Guru Mata Pelajaran (MGMP) pada jenjang SMA dalam menyusun program pembinaan guru sesuai kebutuhan jenjang jabatan fungsional guru (Guru Pertama, Guru Muda, dan Guru Madya). 


\section{METODE}

Penelitian ini merupakan penelitian evaluasi yang digunakan untuk mengkaji kapasitas guru melalui penyelenggaraan penilaian kinerja guru dalam implementasi kompetensi profesional guru melalui penyelenggaraan pendidikan dan pembelajaran di dalam dan di luar kelas yang terselenggara pada satuan pendidikan menengah atas dan menengah kejuruan. Dengan demikian metode yang dipergunakan dalam penelitian ini termasuk dalam model evaluasi dengan pendekatan penelitian secara kualitatif.

Obyek penelitian ini adalah seluruh guru di sekolah binaan (SMAN 2 Banjarmasin dan SMAN 13 Banjarmasin) yang dikelompokkan atas jabatan fungsional guru (Guru Pertama, Guru Muda, dan Guru Madya), dalam masa penilaian tahun 2018. Gambaran rinci penentuan jumlah responden dikelompokkan sebagaimana tabel berikut:

Tabel 1

Jumlah Responden Berdasarkan Kabupaten/Kota

\begin{tabular}{|c|l|l|c|}
\hline No & \multicolumn{1}{|c|}{ Kabupaten } & Jabatan Fungsional & Jumlah \\
\hline 1 & \multirow{2}{*}{ SMA Negeri 2 Banjarmasin } & Pertama & 2 \\
\cline { 3 - 4 } & & Muda & 16 \\
\cline { 3 - 4 } & & Madya & 24 \\
\hline \multirow{2}{*}{2} & SMA Negeri 13 Banjarmasin & Pertama & 0 \\
\cline { 3 - 4 } & & Muda & 9 \\
\cline { 3 - 4 } & & Madya & 68 \\
\hline & \multicolumn{2}{|c|}{ JUMLAH } & 67 \\
\hline
\end{tabular}

Data yang diperoleh akan dianalisis dengan menggunakan analisis pengukuran kinerja model countening stake dengan cara: Analisis instrumen kinerja, pembobotan, penskoran dan penilaian.

1) Analisis Instrumen Kinerja

Kegiatan ini dilaksanakan untuk memastikan bahwa dokumen yang tersedia di setiap satuan pendidikan yang menjadi sample penelitian adalah sama. Instrumen kinerja guru dalam variabel dan indikator pemenuhan indikator sesuai dengan juknis / pedoman penilaian kinerja yang dikeluarkan sesuai dengan Permeneg PAN dan RB No.16 Tahun 2009.

2) Pembobotan

Indikator penilaian kinerja guru atas 4 kompetensi guru dapat dijabarkan sebagai berikut:

\section{Tabel 2}

Indikator Penilaian Kinerja Guru

\begin{tabular}{|c|c|c|c|c|}
\hline No & Kompetensi & Sub Kompetensi & Indikator & Bobot \\
\hline 1. & Pedagogik & Kompetensi 1 & 6 & 2 \\
\cline { 3 - 5 } & & Kompetensi 2 & 6 & 2 \\
\cline { 3 - 5 } & & Kompetensi 3 & 4 & 2 \\
\cline { 3 - 5 } & Kompetensi 4 & 11 & 2 \\
\cline { 3 - 5 } & & Kompetensi 5 & 7 & 2 \\
\cline { 3 - 5 } & & Kompetensi 6 & 6 & 2 \\
\cline { 3 - 5 } & & Kompetensi 7 & 5 & 2 \\
\hline
\end{tabular}




\begin{tabular}{|c|l|c|c|c|}
\hline No & Kompetensi & Sub Kompetensi & Indikator & Bobot \\
\hline 2. & \multirow{2}{*}{ Sosial } & Kompetensi 1 & 5 & 2 \\
\cline { 3 - 5 } & & Kompetensi 2 & 5 & 2 \\
\hline 3. & \multirow{2}{*}{ Kepribadian } & Kompetensi 1 & 8 & 2 \\
\cline { 3 - 5 } & & Kompetensi 2 & 3 & 2 \\
\cline { 3 - 5 } & & Kompetensi 3 & 3 & 2 \\
\hline 4. & Profesional & Kompetensi 1 & 3 & 2 \\
\cline { 3 - 5 } & & Kompetensi 2 & 6 & 2 \\
\hline & JUMLAH & 78 & \\
\hline
\end{tabular}

3) Penskoran

Sesuai dengan buku Pedoman Penilaian Kinerja, maka setiap indikator akan diberi skor 0,1 dan 2. Skor 0 menyatakan indikator tidak dilaksanakan, atau tidak menunjukkan bukti. Skor 1 menyatakan indikator dilaksanakan sebagian, atau ada bukti tetapi tidak lengkap. Skor 2 menyatakan indikator dilaksanakan sepenuhnya, atau ada bukti yang lengkap.

Perolehan skor untuk setiap kompetensi dijumlahkan dan dihitung prosentasinya dengan cara: (Total Skor/Total Skor Maksimum) x 100\%.

Perolehan prosentasi skor pada setiap kompetensi ini kemudian dikonversikan ke dalam nilai 1, 2, 3 dan 4 dengan menggunakan standar $0 \%<\mathrm{X} \leq 25 \%=1$; $25 \%<X \leq 50 \%=2 ; 50 \%<X \leq 75 \%=3 ; 75 \%<X \leq 100 \%=4$

4) Penilaian

Nilai kompetensi tersebut kemudian direkapitulasikan dalam format rekap hasil penilaian kinerja guru untuk mendapatkan nilai total penilaian kinerja guru. Nilai total ini selanjutnya dikonversikan ke dalam skala nilai sesuai Peraturan Menteri Negara Pemberdayaan Aparatur Negara dan Reformasi dan Birokrasi No.16 Tahun 2009. Konversi ini dilakukan dengan menggunakan rumus sebagai berikut:

Nilai $P K G(100)=\frac{\text { Nilai } P K G}{\text { Nilai } P K G \text { tertinggi }} \times 100$

Keterangan:

- Nilai PKG (100) : Nilai PK Guru Pembelajaran dalam skala 0 - 100

- Nilai PKG: Nilai PK Guru Pembelajaran yang diperoleh sebelum dirubah dalam skala $0-100$.

- Nilai PKG Tertinggi: Nilai tertinggi PK Guru yang dapat dicapai, yaitu 56 (14 x 4).

Konversi Nilai Kinerja Hasil PK Guru selanjutnya dikelompokkan ke dalam sebutan:

$\begin{array}{lll}\text { Hasil PK Guru: } & 90,01-100,00 & \text { : Amat baik } \\ & 76,01-90,00 & \text { : Baik } \\ & 60,01-76,00 & \text { : Cukup } \\ & 50,01-60,00 & \text { : Sedang } \\ & \leq 50 & \text { : Kurang }\end{array}$




\section{HASIL DAN PEMBAHASAN}

\section{A. Hasil}

Penilaian kinerja guru dalam penelitian ini diukur melalui empat aspek kompetensi, yaitu kompetensi pedagogik, kompetensi kepribadian, kompetensi sosial dan kompetensi profesional guru. Setiap aspek kompetensi diukur melalui 14 indikator kompetensi profesional guru. Melalui 14 indikator tersebut diharapkan akan terlihat secara rinci dan spesifik akan potret profil kinerja guru di kedua sekolah binaan.

Data sasaran penilaian kinerja guru dalam penelitian ini dilihat dari jabatan fungsional guru yang terdiri atas jabatan guru sebagai guru pertama, guru muda dan guru madya berdasarkan jenis kelamin dapat dilihat sebagaimana tabel berikut:

Tabel 3

Data Sasaran Penilaian Kinerja Guru

\begin{tabular}{|l|l|c|c|c|c|c|c|}
\hline \multirow{2}{*}{\multicolumn{2}{|c|}{ DATA GURU }} & \multicolumn{3}{c|}{ JENIS KELAMIN } \\
\cline { 3 - 8 } & \multicolumn{2}{|c|}{ Laki-Laki } & \multicolumn{2}{c|}{ Perempuan } & \multicolumn{2}{c|}{ Subtotal } \\
\cline { 2 - 8 } & Count & Column N \% & Count & Column N \% & Count & Column N \% \\
\hline \multirow{3}{*}{$\begin{array}{l}\text { JABATAN } \\
\text { FUNGSIONAL } \\
\text { GURU }\end{array}$} & Guru Pertama & 1 & $4,5 \%$ & 1 & $2,2 \%$ & 2 & $2,9 \%$ \\
\cline { 2 - 8 } & Guru Muda & 8 & $36,4 \%$ & 17 & $37,0 \%$ & 25 & $36,8 \%$ \\
\cline { 2 - 8 } & Guru Madya & 13 & $59,1 \%$ & 28 & $60,9 \%$ & 41 & $60,3 \%$ \\
\cline { 2 - 8 } & Subtotal & 22 & $100,0 \%$ & 46 & $100,0 \%$ & 68 & $100,0 \%$ \\
\hline
\end{tabular}

Sumber : Data diolah dari hasil penilaian kinerja guru tahun 2018

Data tersebut menyebutkan, sasaran penilaian kinerja guru dalam penelitian ini dari 22 orang guru laki-laki dan 46 orang guru perempuan, yang terdiri dari guru pertama sebanyak 2 orang $(2,9 \%)$, guru muda $(36,8 \%)$, dan guru madya $(60,3 \%)$.

\section{Tabel 4}

Data Capaian Hasil Penilaian Kinerja Guru

\begin{tabular}{|c|c|c|c|c|c|c|c|c|c|}
\hline \multirow{3}{*}{\multicolumn{2}{|c|}{$\begin{array}{l}\text { CAPAIAN HASIL PENILAIAN } \\
\text { KINERJA GURU }\end{array}$}} & \multicolumn{8}{|c|}{ JABATAN FUNGSIONAL GURU } \\
\hline & & \multicolumn{2}{|c|}{ Guru Pertama } & \multicolumn{2}{|c|}{ Guru Muda } & \multicolumn{2}{|c|}{ Guru Madya } & \multicolumn{2}{|c|}{ Subtotal } \\
\hline & & $\mathrm{N}$ & $\mathrm{N} \%$ & $\mathrm{~N}$ & $\mathrm{~N} \%$ & $\mathrm{~N}$ & $\mathrm{~N} \%$ & $\mathrm{~N}$ & $\mathrm{~N} \%$ \\
\hline \multirow{5}{*}{$\begin{array}{l}\text { NILAI } \\
\text { KINERJA } \\
\text { GURU }\end{array}$} & Kurang & 0 & $0,0 \%$ & 0 & $0,0 \%$ & 0 & $0,0 \%$ & 0 & $0,0 \%$ \\
\hline & Cukup & 0 & $0,0 \%$ & 0 & $0,0 \%$ & 0 & $0,0 \%$ & 0 & $0,0 \%$ \\
\hline & Baik & 2 & $100,0 \%$ & 23 & $92,0 \%$ & 33 & $80,5 \%$ & 58 & $85,3 \%$ \\
\hline & Sangat Baik & 0 & $0,0 \%$ & 2 & $8,0 \%$ & 8 & $19,5 \%$ & 10 & $14,7 \%$ \\
\hline & Subtotal & 2 & $100,0 \%$ & 25 & $100,0 \%$ & 41 & $100,0 \%$ & 68 & $100,0 \%$ \\
\hline
\end{tabular}

Sumber : Data diolah dari hasil penilaian kinerja guru tahun 2018

Data tersebut menyebutkan, hasil capaian penilaian kinerja guru di kedua sekolah binaan yang memperoleh kinerja "baik" sebanyak 58 orang $(85,3 \%)$ dan memperoleh nilai kinerja "sangat baik" sebanyak 10 orang (14,7\%). Selanjutnya hasil penilaian kinerja dilihat dari nilai capaian kinerja rata-rata atas kedua kategori dapat dilihat pada tabel berikut: 
Tabel 5

Capaian Rata-Rata Penilaian Kinerja Guru Berdasarkan Jenis Kelamin

\begin{tabular}{|c|c|c|c|c|c|c|c|c|c|c|}
\hline \multirow{3}{*}{\multicolumn{2}{|c|}{$\begin{array}{l}\text { KATEGORI HASIL PENILAIAN } \\
\text { KINERJA }\end{array}$}} & \multicolumn{9}{|c|}{ PENILAIAN HASIL KINERJA GURU } \\
\hline & & \multicolumn{9}{|c|}{ JENIS KELAMIN } \\
\hline & & \multicolumn{3}{|c|}{ Laki-Laki } & \multicolumn{3}{|c|}{ Perempuan } & \multicolumn{3}{|c|}{ Subtotal } \\
\hline & & Mean & Count & Column N \% & Mean & Count & Column N \% & Mean & Count & Column N \% \\
\hline \multirow{5}{*}{$\begin{array}{l}\text { PENILAIAN } \\
\text { HASIL KINERJA }\end{array}$} & Kurang & & 0 & $0,0 \%$ & & 0 & $0,0 \%$ & & 0 & $0,0 \%$ \\
\hline & Cukup & & 0 & $0,0 \%$ & & 0 & $0,0 \%$ & & 0 & $0,0 \%$ \\
\hline & Baik & 87,50 & 18 & $81,8 \%$ & 87,95 & 40 & $87,0 \%$ & 87,81 & 58 & $85,3 \%$ \\
\hline & Sangat Baik & 93,75 & 4 & $18,2 \%$ & 94,94 & 6 & $13,0 \%$ & 94,46 & 10 & $14,7 \%$ \\
\hline & Subtotal & 88,64 & 22 & $100,0 \%$ & 88,86 & 46 & $100,0 \%$ & 88,79 & 68 & $100,0 \%$ \\
\hline
\end{tabular}

Sumber : Data diolah dari hasil penilaian kinerja guru tahun 2018

Data tersebut menyebutkan, capaian rata-rata hasil penilaian kinerja guru di kedua sekolah binaan yang memperoleh kinerja "baik" memperoleh nilai kinerja rata-rata sebesar 87,81 diraih oleh 58 orang guru dan memperoleh nilai kinerja "sangat baik" memperoleh nilai kinerja guru sebesar 94,46 diraih oleh 10 orang. Data tersebut juga menyebutkan rata-rata capaian hasil penilaian kinerja guru laki-laki mencapai 88,64 dan capaian hasil penilaian kinerja guru perempuan mencapai 88,86. Selanjutnya, untuk mendapat gambaran yang lebih spesifik terhadap capaian kinerja dilihat dari aspek kompetensi profesi guru, dapat dilihat sebagaimana diuraikan pada tabel berikut:

\section{Tabel 6}

Capaian Rata-Rata Penilaian Kinerja Guru Berdasarkan Aspek Kompetensi Guru

\begin{tabular}{|l|c|c|c|c|}
\hline \multirow{2}{*}{ KOMPETENSI } & \multicolumn{4}{|c|}{ JABATAN FUNGSIONAL GURU } \\
\cline { 2 - 5 } & Guru Pertama & Guru Muda & Guru Madya & Subtotal \\
\cline { 2 - 5 } & Mean & Mean & Mean & Mean \\
\hline PEDAGOGIK & 82,14 & 85,28 & 86,85 & 86,13 \\
\hline KEPRIBADIAN & 95,84 & 95,67 & 97,76 & 96,94 \\
\hline SOSIAL & 93,75 & 87,00 & 92,68 & 90,63 \\
\hline PROFESIONAL & 81,25 & 83,00 & 84,76 & 84,01 \\
\hline
\end{tabular}

Sumber : Data diolah dari hasil penilaian kinerja guru tahun 2018

Berdasarkan data tersebut diperoleh gambaran: (1) Hasil capaian rata-rata kompetensi pedagogik guru bagi guru pertama mencapai 82,14, guru muda mencapai 85,28, guru madya mencapai 86,85 dengan rata-rata capaian sebesar 86,13 termasuk dalam kategori "baik". (2) Hasil capaian rata-rata kompetensi kepribadian guru bagi guru pertama mencapai 95,84, guru muda mencapai 95,67, guru madya mencapai 97,76 dengan rata-rata capaian sebesar 96,94 termasuk dalam kategori "sangat baik". (3) Hasil capaian rata-rata kompetensi sosial guru bagi guru pertama mencapai 93,75, guru muda mencapai 87,00, guru madya mencapai 92,68 dengan rata-rata capaian sebesar 90,63 termasuk dalam kategori "sangat baik". (4) Hasil capaian rata-rata kompetensi profesional guru bagi guru pertama mencapai 82,14 , guru muda mencapai 85,28 , guru madya mencapai 86,85 dengan rata-rata capaian sebesar 86,13 termasuk dalam kategori "baik". 
Hasil capaian kinerja guru atas masing-masing aspek kompetensi dapat diuraikan sebagai berikut:

\section{Kompetensi Kepribadian:}

Tabel 7

Capaian Kompetensi Kepribadian Guru

Berdasarkan Jenis Kelamin

\begin{tabular}{|l|l|c|c|c|c|c|c|}
\hline \multirow{2}{*}{} & \multicolumn{9}{|c|}{ JENIS KFLAMIN } \\
\cline { 3 - 8 } \multicolumn{2}{|c|}{ JENIS KOMPETENSI } & \multicolumn{2}{|c|}{ Laki-Laki } & \multicolumn{2}{c|}{ Perempuan } & \multicolumn{2}{c|}{ Subtotal } \\
\cline { 2 - 8 } & Count & Column N \% & Count & Column N \% & Count & Column N \% \\
\hline \multirow{3}{*}{ KEPRIBADIAN } & Kurang & 0 & $0,0 \%$ & 0 & $0,0 \%$ & 0 & $0,0 \%$ \\
\cline { 2 - 9 } & Cukup & 0 & $0,0 \%$ & 0 & $0,0 \%$ & 0 & $0,0 \%$ \\
\cline { 2 - 9 } & Baik & 2 & $9,1 \%$ & 1 & $2,2 \%$ & 3 & $4,4 \%$ \\
\cline { 2 - 8 } & Sangat Baik & 20 & $90,9 \%$ & 45 & $97,8 \%$ & 65 & $95,6 \%$ \\
\cline { 2 - 8 } & Subtotal & 22 & $100,0 \%$ & 46 & $100,0 \%$ & 68 & $100,0 \%$ \\
\hline
\end{tabular}

Sumber : Data diolah dari hasil penilaian kinerja guru tahun 2018

Berdasarkan data tersebut, capaian kompetensi kepribadian dengan kategori "baik" mencapai 4,4\% (3 orang) terdiri atas guru laki-laki sebanyak 2 orang dan 1 orang guru perempuan, dan capaian kinerja dengan kategori "sangat baik" mencapai 95,6\% (65 orang) terdiri atas guru laki-laki sebanyak 20 orang dan 45 orang guru perempuan. Selanjutnya, capaian kompetensi kepribadian guru dilihat dari jabatan fungsional guru dapat dilihat pada tabel berikut:

\section{Tabel 8}

Capaian Kompetensi Kepribadian Guru

Berdasarkan Jabatan Fungsional

\begin{tabular}{|c|c|c|c|c|c|c|c|c|c|}
\hline \multirow{3}{*}{\multicolumn{2}{|c|}{ KOMPETENSI }} & \multicolumn{8}{|c|}{ JABATAN FUNGS IONAL GURU } \\
\hline & & \multicolumn{2}{|c|}{ Guru Pertama } & \multicolumn{2}{|c|}{ Guru Muda } & \multicolumn{2}{|c|}{ Guru Madya } & \multicolumn{2}{|c|}{ Subtotal } \\
\hline & & Count & Table N \% & Count & Table N \% & Count & Table N \% & Count & Table N \% \\
\hline \multirow{5}{*}{ KEPRIBADIAN } & Kurang & 0 & $0,0 \%$ & 0 & $0,0 \%$ & 0 & $0,0 \%$ & 0 & $0,0 \%$ \\
\hline & Cukup & 0 & $0,0 \%$ & 0 & $0,0 \%$ & 0 & $0,0 \%$ & 0 & $0,0 \%$ \\
\hline & Baik & 0 & $0,0 \%$ & 2 & $2,9 \%$ & 1 & $1,5 \%$ & 3 & $4,4 \%$ \\
\hline & Sangat Baik & 2 & $2,9 \%$ & 23 & $33,8 \%$ & 40 & $58,8 \%$ & 65 & $95,6 \%$ \\
\hline & Subtotal & 2 & $2,9 \%$ & 25 & $36,8 \%$ & 41 & $60,3 \%$ & 68 & $100,0 \%$ \\
\hline
\end{tabular}

Sumber : Data diolah dari hasil penilaian kinerja guru tahun 2018

Berdasarkan data tersebut, capaian kompetensi kepribadian dengan kategori "baik" bagi guru pertama sebanyak 0 orang $(0,0 \%)$ dan guru muda 2 orang $(2,9 \%)$ dan guru madya 1 orang $(1,5 \%)$ dan capaian penilaian dengan kategori "sangat baik" bagi guru pertama sebanyak 2 orang $(2,9 \%)$ dan guru muda 23 orang $(2,2 \%)$ dan guru madya 40 orang $(95,6 \%)$. 
2. Kompetensi Pedagogik:

Tabel 9

Capaian Kompetensi Pedagogik Guru

Berdasarkan Jenis Kelamin

\begin{tabular}{|l|l|c|c|c|c|c|c|}
\hline \multicolumn{2}{|c|}{ JENIS KOMPETENSI } & \multicolumn{3}{|c|}{ JENIS KFLAMIN } \\
\cline { 2 - 9 } & \multicolumn{2}{|c|}{ Laki-Laki } & \multicolumn{2}{c|}{ Perempuan } & \multicolumn{3}{c|}{ Subtotal } \\
\cline { 2 - 9 } & Count & Column N \% & Count & Column N \% & Count & Column N \% \\
\hline \multirow{5}{*}{ PEDAGOGIK } & Kurang & 0 & $0,0 \%$ & 0 & $0,0 \%$ & 0 & $0,0 \%$ \\
\cline { 2 - 9 } & Cukup & 0 & $0,0 \%$ & 0 & $0,0 \%$ & 0 & $0,0 \%$ \\
\cline { 2 - 9 } & Baik & 17 & $77,3 \%$ & 40 & $87,0 \%$ & 57 & $83,8 \%$ \\
\cline { 2 - 9 } & Sangat Baik & 5 & $22,7 \%$ & 6 & $13,0 \%$ & 11 & $16,2 \%$ \\
\cline { 2 - 9 } & Subtotal & 22 & $100,0 \%$ & 46 & $100,0 \%$ & 68 & $100,0 \%$ \\
\hline
\end{tabular}

Sumber : Data diolah dari hasil penilaian kinerja guru tahun 2018

Berdasarkan data tersebut, capaian kompetensi pedagogik dengan kategori "baik" mencapai 83,8\% (57 orang) terdiri atas guru laki-laki sebanyak 17 orang dan 40 orang guru perempuan, dan capaian kinerja dengan kategori "sangat baik" mencapai 16,2\% (11 orang) terdiri atas guru laki-laki sebanyak 5 orang dan 6 orang guru perempuan. Selanjutnya, capaian kompetensi pedagogik guru dilihat dari jabatan fungsional guru dapat dilihat pada tabel berikut:

Tabel 10

Capaian Kompetensi Kepribadian Guru

Berdasarkan Jabatan Fungsional

\begin{tabular}{|c|c|c|c|c|c|c|c|c|c|}
\hline \multirow{3}{*}{\multicolumn{2}{|c|}{ KOMPETENSI }} & \multicolumn{8}{|c|}{ JABATAN FUNGSIONAL GURU } \\
\hline & & \multicolumn{2}{|c|}{ Guru Pertama } & \multicolumn{2}{|c|}{ Guru Muda } & \multicolumn{2}{|c|}{ Guru Madya } & \multicolumn{2}{|c|}{ Subtotal } \\
\hline & & Count & Table N \% & Count & Table N \% & Count & Table N \% & Count & Table N \% \\
\hline \multirow{5}{*}{ PEDAGOGIK } & Kurang & 0 & $0,0 \%$ & 0 & $0,0 \%$ & 0 & $0,0 \%$ & 0 & $0,0 \%$ \\
\hline & Cukup & 0 & $0,0 \%$ & 0 & $0,0 \%$ & 0 & $0,0 \%$ & 0 & $0,0 \%$ \\
\hline & Baik & 2 & $2,9 \%$ & 22 & $32,4 \%$ & 33 & $48,5 \%$ & 57 & $83,8 \%$ \\
\hline & Sangat Baik & 0 & $0,0 \%$ & 3 & $4,4 \%$ & 8 & $11,8 \%$ & 11 & $16,2 \%$ \\
\hline & Subtotal & 2 & $2,9 \%$ & 25 & $36,8 \%$ & 41 & $60,3 \%$ & 68 & $100,0 \%$ \\
\hline
\end{tabular}

Sumber : Data diolah dari hasil penilaian kinerja guru tahun 2018

Berdasarkan data tersebut, capaian kompetensi pedagogik dengan kategori "baik" bagi guru pertama sebanyak 2 orang (2,9\%) dan guru muda 22 orang $(32,4 \%)$ dan guru madya 57 orang $(83,8 \%)$ dan capaian penilaian dengan kategori "sangat baik" bagi guru pertama sebanyak 0 orang $(0,0 \%)$ dan guru muda 3 orang $(4,4 \%)$ dan guru madya 11 orang $(16,2 \%)$. 


\section{Kompetensi Sosial:}

Tabel 11

Capaian Kompetensi Sosial Guru

Berdasarkan Jenis Kelamin

\begin{tabular}{|l|l|c|c|c|c|c|c|}
\hline \multirow{2}{*}{} & \multicolumn{6}{|c|}{ JENIS KELAMIN } \\
\cline { 3 - 8 } \multicolumn{2}{|c|}{ JENIS KOMPETENSI } & \multicolumn{2}{|c|}{ Laki-Laki } & \multicolumn{2}{c|}{ Perempuan } & \multicolumn{2}{c|}{ Subtotal } \\
\cline { 2 - 8 } & Count & Column N \% & Count & Column N \% & Count & Column N \% \\
\hline \multirow{4}{*}{ SOSIAL } & Kurang & 0 & $0,0 \%$ & 0 & $0,0 \%$ & 0 & $0,0 \%$ \\
\cline { 2 - 9 } & Cukup & 6 & $27,3 \%$ & 5 & $10,9 \%$ & 11 & $16,2 \%$ \\
\cline { 2 - 9 } & Baik & 8 & $36,4 \%$ & 20 & $43,5 \%$ & 28 & $41,2 \%$ \\
\cline { 2 - 9 } & Sangat Baik & 8 & $36,4 \%$ & 21 & $45,7 \%$ & 29 & $42,6 \%$ \\
\cline { 2 - 8 } & Subtotal & 22 & $100,0 \%$ & 46 & $100,0 \%$ & 68 & $100,0 \%$ \\
\hline
\end{tabular}

Sumber : Data diolah dari hasil penilaian kinerja guru tahun 2018

Berdasarkan data tersebut, capaian kompetensi sosial dengan kategori "cukup" mencapai 16,2\% (11 orang) terdiri atas guru laki-laki sebanyak 6 orang dan 5 orang guru perempuan, kategori "baik" mencapai 41,2\% (28 orang) terdiri atas guru laki-laki sebanyak 8 orang dan 20 orang guru perempuan dan capaian kinerja dengan kategori "sangat baik" mencapai 42,6\% (29 orang) terdiri atas guru laki-laki sebanyak 8 orang dan 29 orang guru perempuan. Selanjutnya, capaian kompetensi sosial guru dilihat dari jabatan fungsional guru dapat dilihat pada tabel berikut:

Tabel 12

Capaian Kompetensi Sosial Guru

Berdasarkan Jabatan Fungsional

\begin{tabular}{|c|c|c|c|c|c|c|c|c|c|}
\hline & & \multicolumn{8}{|c|}{ JABATAN FUNGS IONAL GURU } \\
\hline \multicolumn{2}{|c|}{ KOMPETENS I } & \multicolumn{2}{|c|}{ Guru Pertama } & \multicolumn{2}{|c|}{ Guru Muda } & \multicolumn{2}{|c|}{ Guru Madya } & \multicolumn{2}{|c|}{ Subtotal } \\
\hline & & Count & Table N \% & Count & Table N \% & Count & Table N \% & Count & Table N \% \\
\hline \multirow{5}{*}{ SOSIAL } & Kurang & 0 & $0,0 \%$ & 0 & $0,0 \%$ & 0 & $0,0 \%$ & 0 & $0,0 \%$ \\
\hline & Cukup & 0 & $0,0 \%$ & 6 & $8,8 \%$ & 5 & $7,4 \%$ & 11 & $16,2 \%$ \\
\hline & Baik & 1 & $1,5 \%$ & 13 & $19,1 \%$ & 14 & $20,6 \%$ & 28 & $41,2 \%$ \\
\hline & Sangat Baik & 1 & $1,5 \%$ & 6 & $8,8 \%$ & 22 & $32,4 \%$ & 29 & $42,6 \%$ \\
\hline & Subtotal & 2 & $2,9 \%$ & 25 & $36,8 \%$ & 41 & $60,3 \%$ & 68 & $100,0 \%$ \\
\hline
\end{tabular}

Sumber : Data diolah dari hasil penilaian kinerja guru tahun 2018

Berdasarkan data tersebut, capaian kompetensi sosial dengan kategori "cukup" bagi guru pertama sebanyak 0 orang $(0,0 \%)$ dan guru muda 6 orang $(8,8 \%)$ dan guru madya 5 orang $(16,2 \%)$, kategori "baik" bagi guru pertama sebanyak 1 orang $(1,5 \%)$ dan guru muda 13 orang $(19,1 \%)$ dan guru madya 14 orang $(20,6 \%)$, dan capaian penilaian dengan kategori "sangat baik" bagi guru pertama sebanyak 1 orang $(1,5 \%)$ dan guru muda 6 orang $(8,8 \%)$ dan guru madya 29 orang $(42,6 \%)$. 


\section{Kompetensi Profesional:}

Tabel 13

Capaian Kompetensi Profesional Guru

Berdasarkan Jenis Kelamin

\begin{tabular}{|l|l|c|c|c|c|c|c|}
\hline \multirow{2}{*}{} & \multicolumn{6}{|c|}{ JENIS KELAMIN } \\
\cline { 3 - 8 } \multicolumn{2}{|c|}{ JENIS KOMPETENSI } & \multicolumn{2}{|c|}{ Laki-Laki } & \multicolumn{2}{c|}{ Perempuan } & \multicolumn{2}{c|}{ Subtotal } \\
\cline { 3 - 8 } & Count & Column N \% & Count & Column N \% & Count & Column N \% \\
\hline \multirow{3}{*}{ PROFESIONAL } & Kurang & 0 & $0,0 \%$ & 0 & $0,0 \%$ & 0 & $0,0 \%$ \\
\cline { 2 - 8 } & Cukup & 8 & $36,4 \%$ & 17 & $37,0 \%$ & 25 & $36,8 \%$ \\
\cline { 2 - 8 } & Baik & 12 & $54,5 \%$ & 23 & $50,0 \%$ & 35 & $51,5 \%$ \\
\cline { 2 - 8 } & Sangat Baik & 2 & $9,1 \%$ & 6 & $13,0 \%$ & 8 & $11,8 \%$ \\
\cline { 2 - 8 } & Subtotal & 22 & $100,0 \%$ & 46 & $100,0 \%$ & 68 & $100,0 \%$ \\
\hline
\end{tabular}

Sumber : Data diolah dari hasil penilaian kinerja guru tahun 2018

Berdasarkan data tersebut, capaian kompetensi profesional dengan kategori "cukup" mencapai 36,8\% (25 orang) terdiri atas guru laki-laki sebanyak 8 orang dan 17 orang guru perempuan, kategori "baik" mencapai 51,5\% (35 orang) terdiri atas guru laki-laki sebanyak 12 orang dan 23 orang guru perempuan dan capaian kinerja dengan kategori "sangat baik" mencapai 11,8\% (8) terdiri atas guru laki-laki sebanyak 2 orang dan 6 orang guru perempuan. Selanjutnya, capaian kompetensi sosial guru dilihat dari jabatan fungsional guru dapat dilihat pada tabel berikut:

Tabel 14

Capaian Kompetensi Profesional Guru Berdasarkan Jabatan Fungsional

\begin{tabular}{|c|c|c|c|c|c|c|c|c|c|}
\hline \multirow{3}{*}{\multicolumn{2}{|c|}{ KOMPETENS I }} & \multicolumn{8}{|c|}{ JABATAN FUNGS IONAL GURU } \\
\hline & & \multicolumn{2}{|c|}{ Guru Pertama } & \multicolumn{2}{|c|}{ Guru Muda } & \multicolumn{2}{|c|}{ Guru Madya } & \multicolumn{2}{|c|}{ Subtotal } \\
\hline & & Count & Table N \% & Count & Table N \% & Count & Table N \% & Count & Table N \% \\
\hline \multirow{5}{*}{ PROFESIONAL } & Kurang & 0 & $0,0 \%$ & 0 & $0,0 \%$ & 0 & $0,0 \%$ & 0 & $0,0 \%$ \\
\hline & Cukup & 1 & $1,5 \%$ & 11 & $16,2 \%$ & 13 & $19,1 \%$ & 25 & $36,8 \%$ \\
\hline & Baik & 1 & $1,5 \%$ & 11 & $16,2 \%$ & 23 & $33,8 \%$ & 35 & $51,5 \%$ \\
\hline & Sangat Baik & 0 & $0,0 \%$ & 3 & $4,4 \%$ & 5 & $7,4 \%$ & 8 & $11,8 \%$ \\
\hline & Subtotal & 2 & $2,9 \%$ & 25 & $36,8 \%$ & 41 & $60,3 \%$ & 68 & $100,0 \%$ \\
\hline
\end{tabular}

Sumber : Data diolah dari hasil penilaian kinerja guru tahun 2018

Berdasarkan data tersebut, capaian kompetensi profesional dengan kategori "cukup" bagi guru pertama sebanyak 1 orang $(1,5 \%)$ dan guru muda 11 orang $(16,2 \%)$ dan guru madya 13 orang $(19,1 \%)$, kategori "baik" bagi guru pertama sebanyak 1 orang $(1,5 \%)$ dan guru muda 11 orang $(16,2 \%)$ dan guru madya 23 orang $(33,8 \%)$, dan capaian penilaian dengan kategori "sangat baik" bagi guru pertama sebanyak 0 orang $(0,0 \%)$ dan guru muda 3 orang $(4,4 \%)$ dan guru madya 5 orang $(7,4 \%)$. 


\section{B. Pembahasan}

Pelaksanaan Penelitian ini dilaksanakan dengan perencanaan jadwal kegiatan sebagai berikut:

1. Capaian hasil penilaian kinerja terhadap guru di SMAN 2 dan SMAN 13 Banjarmasin menujukkan hasil "baik" dicapai oleh 58 orang guru dengan ratarata capaian hasil penilaian sebesar 87,81 dan hasil penilaian dengan kategori "sangat baik" sebanyak 10 orang dengan nilai rata-rata sebesar 94,45. Hasil penilaian ini menjelaskan bahwa secara umum kinerja guru di kedua sekolah menunjukkan hasil yang baik. Sekolah secara bersama-sama memiliki kompetensi sumber daya manusia yang baik sebagai modal dasar dalam membangun karakter bagi peserta didik.

2. Capaian hasil penilaian kinerja guru memiliki perbedaan rata-rata pada masing-masing aspek. Hasil penilaian kinerja pada kompetensi pedagogik 86,13 (baik), kompetensi kepribadian 96,94 (sangat baik), kompetensi sosial 90,63 (sangat baik) dan pada kompetensi profesional 84,01 (baik). Hasil ini menggambarkan pada kompetensi kepribadian dan sosial menunjukkan hasil yang optimal, sedangkan pada kompetensi pedagogik dan profesional masih terdapat hasil beberapa guru yang belum menunjukkan hasil penilaian yang optimal. Terdapat perbedaan atas kedua kelompok kompetensi tersebut. Gambaran ini menunjukkan kinerja guru pada kompetensi pedagogik dan profesional perlu menjadi perhatian khusus bagi setiap pembina di sekolah ini.

3. Capaian kompetensi kepribadian; capaian rata-rata nilai berdasarkan jabatan fungsional guru menunjukkan capaian yang sangat baik, sehingga tidak ada terindikasi bahwa kompetensi kepribadian guru mendapatkan nilai cukup atau bahkan kurang. Hal ini menggambarkan bahwa tidak ditemukan adanya keraguan bahwa guru adalah tetap menjadi panutan dan telada dalam membangun karakter peserta didiknya.

4. Capaian kompetensi sosial; capaian rata-rata nilai berdasarkan jabatan fungsional guru menunjukkan nilai baik dan sangat baik dengan akumulasi mencapai 83,8\%, namun demikian masih terdapat sekitar 16,2\% memiliki nilai kinerja "cukup", hal ini menggambarkan masih ditemukan sekitar 28 orang guru yang memiliki tingkat perhatian terhadap sekolah dalam dimensi sosial masih belum optimal. Aspek kompetensi yang menjadi pertimbangan dalam pembinaan adalah: (1) bersikap inklusif, bertindak obyektif, serta tidak diskriminatif, dan (2) komunikasi dengan sesama guru, tenaga kependidikan, orang tua, peserta didik, dan masyarakat

5. Capaian kompetensi pedagogik; capaian rata-rata nilai berdasarkan jabatan fungsional guru terdapat perbedaan. Kenaikan jabatan fungsional guru dari guru pertama, guru muda dan guru madya menunjukkan hasil penilaian pada aspek kompetensi pedagogik mendapat nilai capaian yang meningkat seiring dengan kenaikan pangkat guru. Kenyataan ini bisa dijelaskan bahwa setiap kenaikan pangkat guru tentu diiringi dengan pengalaman masa kerja dan pengembangan keprofesian yang dilaksanakan oleh guru baik ketika mengikuti berbagai diklat dan pelatihan maupun bentuk kegiatan pengembangan diri lainnya seperti penyusunan karya tulis ilmiah. Aspek kompetensi yang menjadi perhatian dari pembinaan adalah: (1) menguasai karakteristik peserta didik, (2) menguasai teori belajar dan prinsip-prinsip 
pembelajaran yang medidik, (3) pengembangan kurikulum, (4) kegiatan pembelajaran yang mendidik, (5) pengembangan potensi peserta didik, (6) komunikasi dengan peserta didik, (7) penilaian dan evaluasi.

6. Capaian kompetensi profesional; capaian rata-rata nilai berdasarkan jabatan fungsional guru. Kenaikan jabatan fungsional guru dari guru pertama, guru muda dan guru madya menunjukkan hasil penilaian pada aspek kompetensi profesional mendapat nilai capaian yang meningkat seiring dengan kenaikan pangkat guru. Kenyataan ini bisa dijelaskan bahwa setiap kenaikan pangkat guru tentu diiringi dengan pengalaman masa kerja dan pengembangan keprofesian yang dilaksanakan oleh guru baik ketika mengikuti berbagai diklat dan pelatihan maupun bentuk kegiatan pengembangan diri lainnya seperti penyusunan karya tulis ilmiah. Namun demikian, ketika hasil penilaian ini dielaborasi dengan pencapaian secara perorangan, masih ditemukan adanya nilai pada aspek ini yang mendapatkan nilai "cukup" sebanyak 25 orang, baik oleh guru pertama, guru muda dan guru madya. Hal ini menunjukkan tidak semua kenaikan pangkat dapat mempengaruhi hasil kinerja profesional seseorang, karena masih terdapat sekitar 36,8\% yang memiliki nilai kompetensi cukup. Aspek kompetensi yang menjadi sasaran dalam pembinaan guru oleh pengawas sekolah adalah (1) penguasaan materi, struktur, konsep dan pola pikir keilmuan yang mendukung mata pelajaran yang diampu, (2) mengembangkan keprofesionalan melalui tindakan yang reflektif.

\section{SIMPULAN}

1. Kemampuan guru menjabarkan kompetensi pedagogik dalam proses pendidikan dan pembelajaran di sekolah dengan kategori "baik" mencapai $83,8 \%$ (57 orang) terdiri atas guru laki-laki sebanyak 17 orang dan 40 orang guru perempuan, dan capaian kinerja dengan kategori "sangat baik" mencapai $16,2 \%$ (11 orang) terdiri atas guru laki-laki sebanyak 5 orang dan 6 orang guru perempuan.

2. Kemampuan guru menjabarkan kompetensi kepribadian dalam proses pembelajaran dan proses pendidikan di sekolah dengan kategori "baik" mencapai 4,4\% (3 orang) terdiri atas guru laki-laki sebanyak 2 orang dan 1 orang guru perempuan, dan capaian kinerja dengan kategori "sangat baik" mencapai 95,6\% (65 orang) terdiri atas guru laki-laki sebanyak 20 orang dan 45 orang guru perempuan.

3. Kemampuan menjabarkan kompetensi sosial dalam proses pendidikan dan pembelajaran di dalam maupun di luar kelas menunjukkan nilai baik dan sangat baik dengan akumulasi mencapai $83,8 \%$, namun masih terdapat $16,2 \%$ memiliki nilai kinerja "cukup yang berarti memiliki tingkat perhatian terhadap sekolah dalam dimensi sosial masih belum optimal.

4. Kemampuan menjabarkan kompetensi profesional pendidikan dan pembelajaran di dalam maupun di luar kelas dengan kategori "cukup" bagi guru pertama sebanyak 1 orang $(1,5 \%)$ dan guru muda 11 orang $(16,2 \%)$ dan guru madya 13 orang $(19,1 \%)$, kategori "baik" bagi guru pertama sebanyak 1 orang $(1,5 \%)$ dan guru muda 11 orang $(16,2 \%)$ dan guru madya 23 orang $(33,8 \%)$, dan capaian penilaian dengan kategori "sangat baik" bagi guru pertama sebanyak 0 orang $(0,0 \%)$ dan guru muda 3 orang $(4,4 \%)$ dan guru madya 5 orang $(7,4 \%)$. 


\section{DAFTAR RUJUKAN}

Hamdani Mamid, (2103), Pengembangan Sistem Pendidikan di Indonesia, Bandung: Pustaka Setia.

Imran, A. (1995), Pembinaan Guru di Indonesia, Jakarta: Pustaka Jaya.

Kementerian Pendidikan Nasional, (2010), Pedoman Pelaksanaan Penilaian Kinerja Guru, Pembinaan dan Pengembangan Profesi Guru, Jakarta: Direktorat Jenderal Peningkatan Mutu Pendidik dan Tenaga Kependidikan.

Mark et. al., (1991), Handbook Educational Supervision A Guide for The Practition, Boston: Allyn \& Bacon Inc.

Peter, D.E. (1994), Supervision in Social Work: A Method of Student Trainning and Staf Development, London: George Allen \& Unwin.

Republik Indonesia, (2014), Undang-Undang Nomor 20 Tahun 2003 Tentang Sistem Pendidikan Nasional. Bandung: Cirta Umbara.

Republik Indonesia, (2014), “Undang-Undang Nomor 14 Tahun 2005 tentang Guru dan Dosen”, Bandung: Cirta Umbara.

Sergiovani, T.J. \& Starrat, R.J. (1993), Supervision Human Perspective, New York: McGraw Hill Book Company. 